\title{
Roles of Estrogens in Prostate Cancer Development via the Modulation of DNA-Repair System
}

\author{
Akari Minami", Atsuko Nakanishi, Yasuko Kitagishi, Yasunori Ogura, and Satoru Matsuda*\# \\ Department of Food Science and Nutrition, Nara Women's University, Nara Women's University, Kita-Uoya Nishimachi, \\ Nara 630-8506, Japan \\ ${ }^{\#}$ The authors contributed equally to this work
}

\begin{abstract}
Received: July 26, 2014; Accepted: December 02, 2014; Published: December 22, 2014
*Corresponding author: Satoru Matsuda, Department of Food Science and Nutrition, Nara Women's University, Nara Women's University, Kita-Uoya Nishimachi, Nara 630-8506, Japan, Tel: +81-742-20-3451; Fax: +81-742-20-3451; E-mail: smatsuda@cc.nara-wu.ac.jp
\end{abstract}

\begin{abstract}
Defects in DNA damage-response and in DNA repair often cause an increase in cancer incidence. Roles of the DNA repair are associated with modulation of hormone signaling pathway. Molecular basis for the progression of prostate cancer which is the most common neoplasm in male population remains an important subject in management of the male cancer. In addition, the molecular mechanisms by which pathogenesis may affect the prostate cancer are poorly elucidated. Epidemiological studies indicate that widerange of lifestyle might alter the development of the prostate cancer. It has also been shown that exposure to estrogenic hormones changes the expression of epigenetic regulatory genes involved in the DNA repair system. We have attempted to review the function of DNA repair molecules at a viewpoint of prostate carcinogenesis and of lifestyle related DNA damages, providing an understanding on the molecular mechanisms by which estrogen may employ their action on the regulation of prostate cancer.
\end{abstract} BRCA1

Keywords: Prostate Cancer; DNA repair; Estrogen; ATM; p53;

\section{Abbreviations}

ATM: Ataxia Telangiectasia-Mutated; BPA: Bisphenol A; ER: Estrogen Receptor; BRCA1: Breast Cancer Susceptibility Gene 1; ERE: Estrogen Response Element; ERK: Extracellular SignalRegulated Kinase; GSK-3: Glycogen Synthase Kinase 3; IR: Infrared Radiation; MAPK: Mitogen Activated Protein Kinase; MSH2: Muts Homolog 2; PMS2: Post-Meiotic Segregation Increased 2; PSA: Prostate-Specific Antigen; ROS: Reactive Oxygen Species, WAF-1: Wild-Type Activating Fragment-1

\section{Introduction}

Prostate cancer is the most common malignancy in men worldwide [1,2], which is also known to be a hormoneresponsive cancer [3]. There are evidences supporting a role for several hormones in stimulating the cancer cell growth [3]. Accordingly, the risk factors of prostate cancer may act at least through hormonal mechanisms [1,2]. Various environmental endocrine disruptors such as Bisphenol A (BPA), which is widely used in the production of plastic polycarbonate, have been shown to make disorders in sexual organs including the prostate gland [4]. Such environmental hormones may play a critical role in influencing for triggering prostate disease [5]. While numerous factors are involved in prostate carcinogenesis [6,7], epidemiological studies have reported a relationship between elevated circulating estrogen levels and prostate diseases [8]. A seminent levels of estrogen are strongly involved in DNA repair system, the signaling pathway of DNA repair may also play a key role in the progression of prostate diseases $[9,10]$. Generally, prostate cancer is classified into three risk groups based on the Gleason score, Prostate-Specific Antigen (PSA) level, and clinical staging [11]. Because the drug which blocks androgenic hormone activation significantly reduces the prostate cancer risk [12], those risk factors may act through androgenic hormonal mechanisms.

Evidences indicate that foodstuffs containing selenium as well as lycopene probably protect against prostate cancer [13], whereas surplus consumption of the supplements containing calcium are a probable risk factor of this cancer [14]. In addition, a recent review has found that there are protective effects of soy foods and high vitamin D levels in human prostate cancer [15]. Furthermore, it is suggested that low dose of selenium specifically stimulates the repair of oxidative DNA damage in prostate cancer cells [16]. Therefore, consumption of certain diets rich in these bioactive nutrients may offer an alternative for prevention of prostate cancer. Also, epidemiological and prospective studies indicate that lifestyle-changes might alter the development of prostate cancer [17]. However, the molecular mechanisms by which improvements in diets and lifestyle may affect the microenvironment in prostate are poorly clarified. Here, we review the function of DNA repair molecules involved in prostate carcinogenesis and hormone related cancer cell regulation.

\section{Estrogens involved in prostate cancer development}

Sex hormones, such as estrogen, androgen, and progesterone frequently contribute to the initiation and promotion of various type of cancer-development through the specific hormone 
receptors. Therefore, not only androgens but also estrogens may promote prostate cancer [18]. In fact, prolonged exposure to an elevated level of estrogens plays a role in the development of prostate cancer [19]. Furthermore, fetal exposure to BPA increases the hypertrophic mass of prostate on mature ages in mice [20]. Exposure to $17 \beta$-estradiol in neonates brings increased incidence of prostate intra-epithelial hyperplasia [21]. In addition, exposure to high level of estrogens during early developmental stage induces prostate cancer development in the life later [21]. Variation in Estrogen Receptor (ER) activities with the specific ligands and/or with genetic alterations may also modulate the prostate cancer risk [22]. However, increased consumption of phytoestrogens such as genistein, a wellknown phytoestrogen as well as a tyrosine-kinase inhibitor, has been associated with a decreased risk of prostate cancer [23]. A combination of selenium and the genistein may offer better efficacy in prostate cancer prevention [24]. In addition, the phytoestrogens protect cells from Reactive Oxygen Species (ROS) by scavenging radicals, up-regulate the expression of GSK$3 \beta$, enhance GSK-3 $\beta$ binding to $\beta$-catenin, and induce apoptotic cell death [25], which suggests that phytoestrogens could induce cancer cell apoptosis and then block cancer cell proliferation. The phytoestrogens have also been found to inhibit the molecules in Mitogen Activated Protein Kinase (MAPK) [26], and in p38-MAPK by TGF- $\beta$ pathway [27], inhibiting cell invasion and cell metastasis of the prostate cancer. Down-regulation of the p38-MAPK signal decreases MutS Homolog 2 (MSH2) expressions, and then enhances the cytotoxic effect. The MSH2 plays a central role in promoting genetic stability by correcting DNA replication-errors. Decreased MSH2 expression in prostate cancer cells has been correlated with an overall recurrence of free interval, and the decreased protein level may be correlated with an increased risk of cancer development [28]. Down-regulation of the MSH2gene is also associated with hormone-independence of prostate cancer. The MSH2 expression is associated with the expression of p53, whereas it negatively correlates to the expression of ER [29]. Increased Post-Meiotic Segregation increased 2 (PMS2) expression appears to be negatively correlated with prognosis of prostate cancer [30,31], which may confer DNA damage tolerance. In addition, the loss of PMS2 expression may serve as a marker for progression of prostate cancer [32,33]. Both MSH2 and PMS2 are known to be one of the microsatellite instability markers. Increasing evidences are suggesting an association between estrogens and carcinogenesis with the microsatellite instability.

Dimerizing receptors activated with estrogen associate to chromatin. Two ER subtypes, ER $\alpha$ and ER $\beta$, are encoded on human chromosomes 6q25.1 [34] and chromosome 14q2224 [35], respectively. Activation of the ER $\alpha$ is thought to be proliferative, whereas the ER $\beta$ is thought to induce apoptosis. By the way, the ER $\beta$ was discovered in human prostate gland [36]. The activated ER acts as a transcription factor that binds to an estrogen response element (ERE) in the chromatin [37]. Both ER $\alpha$ and ER $\beta$ bind to the same ERE, but the ER $\alpha$ binds with higher affinity than the ER $\beta$ does so $[38,39]$. In a DNA repair system, the MSH2 is a key protein which has been shown a potent co-activator of the ER $\alpha$ [40]. Reduced expression of ER $\beta$ correlates with increased prostate cancer risk, suggesting that ER $\beta$ may be pro-apoptotic and anti-metastatic against prostate cancer [41]. In general, ER $\beta$ may antagonize the actions of ER $\alpha$ [42], by binding and suppressing ER $\alpha$ [43]. Activation of ER $\beta$ may induce apoptosis even in normal prostatic basal cells [41], suggesting that some therapies based on estrogens may improve several prostate diseases. In addition, the use of estrogens has an effect through pituitary mediated suppression of androgens secretion $[44,45]$. However, there seems to be local direct actions of estrogens on prostate cells mediated via the ER subtypes. For example, estrogens down-regulate the androgen receptor of prostate cells via the ER $\beta$, resulting in an altered response to hormone-stimulus and different effects against prostate cancer [46-48]. Development of ER specific and/or selective modulators may improve the adverse effects mediated by ER $\alpha$ in the treatment of prostate cancer.

\section{Estrogen signaling involved in DNA repair system}

Some of normal and cancer cells express ERs, and their proliferation is stimulated by estrogen [49]. Elevated exposure to estrogens stimulates an incidence to develop random genetic errors during the cell proliferation, which in turn increases the possibility that severe DNA damage occurs. Additionally, several oxidative metabolites caused by activated cytochrome enzymes with estrogens can produce unstable adducts with DNAs and/or chromatins leading to DNA mutations [50]. Excessive amounts of estrogenic adducts can thus lead to initiation of cancer. For example, metabolites of estrogens react with DNA to create the de-purinating adduct, which may also generate the mutations leading to the initiation of cancer [51]. Consequently, analyzing profiles of estrogen metabolites and de-purinating DNA adducts in urine may be a potential biomarker for prostate cancer [52]. DNA repair system is an enormously conserved DNA excision and incision process that maintains DNA fidelity through the repair of the damaged nucleotides. Studies have shown an association between DNA repair insufficiency and loss of ERs as well as androgen receptors [53]. Genetic defects in the DNA repair mechanisms and/or down-regulation of DNA damageresponse genes promote genomic instability [54]. Cells are therefore equipped with multiple DNA repair mechanisms to the strict maintenance of genomic stability. A chief molecule of DNA impairment recognition is ATM [55], which is a cell cycle checkpoint kinase that phosphorylates a lot of proteins including p53 and BRCA1 tumor suppressors in response to DNA damages (Figure 1). Schematic structures of the molecules are shown in Figure 2. It has been shown that inactivation of ATM is a critical step in genomic instability and the prostate carcinogenesis [56]. One of the additional consequences of defective DNA repair is cellular hyper-sensitivity to DNA damaging agents [57]. The p53 is an important transcription factor which regulates lots of genes and protects against genomic instability. Expression of p21WAF-1, one of the downstream transcriptional targets of p53, is elevated in response to DNA damage in estrogen treated cells. The ATM and p53 may be a functional center in the network linked to key molecules that are regulated by DNA damage and hormones. Besides, a crosstalk between p53 and hormone signaling suggests that p53 activation may enhance anti-cancer 


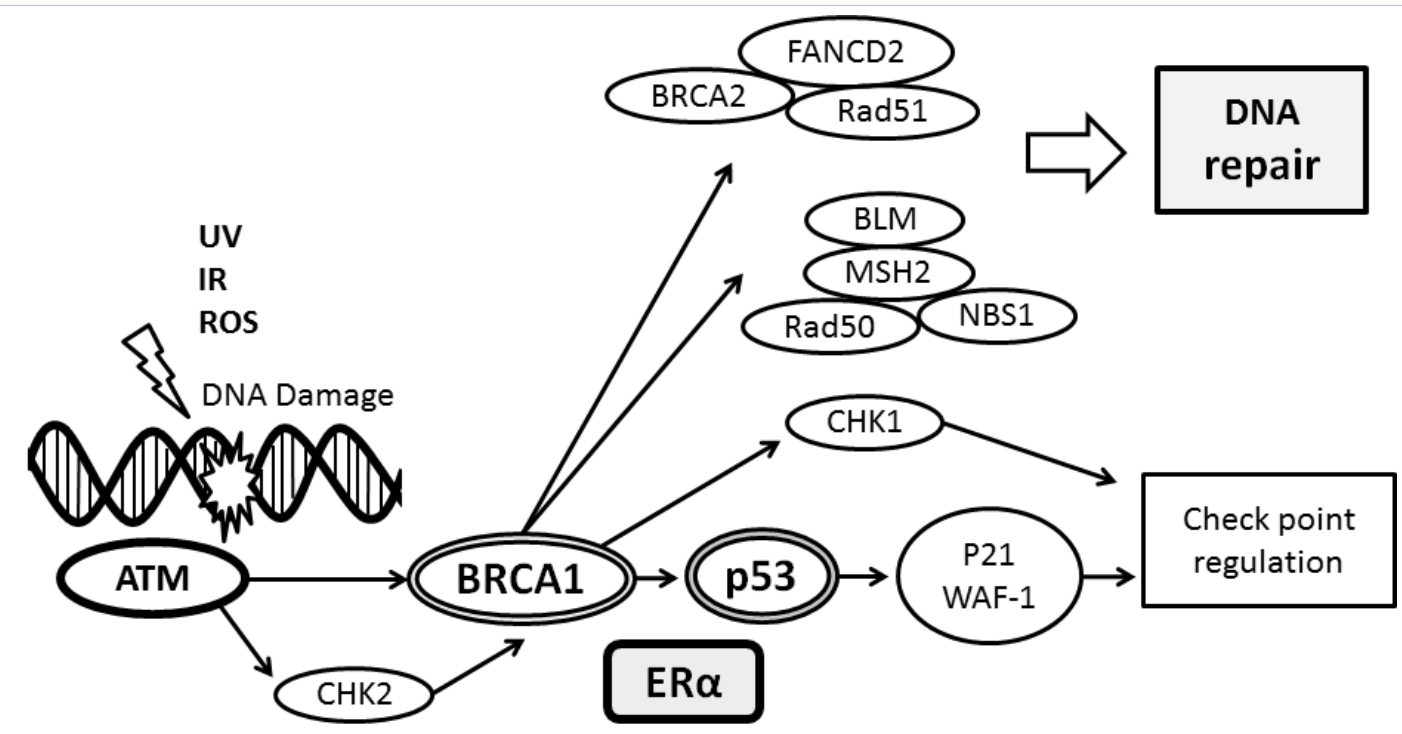

Figure 1: Schematic depiction and overview of the checkpoint regulation and DNA repair of cell cycle signaling via ATM, BRCA1, and p53.Examples of the molecule known to act on the regulatory pathway are shown. Note that some critical pathways have been omitted for clarity.

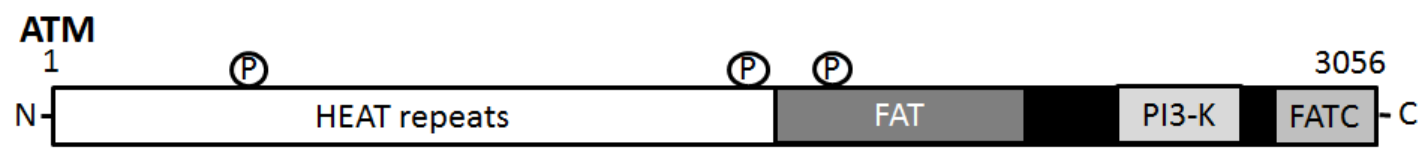

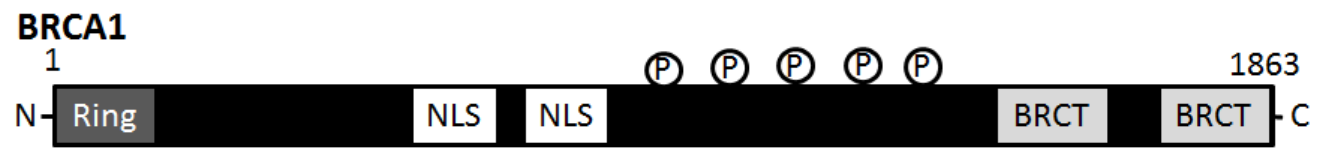
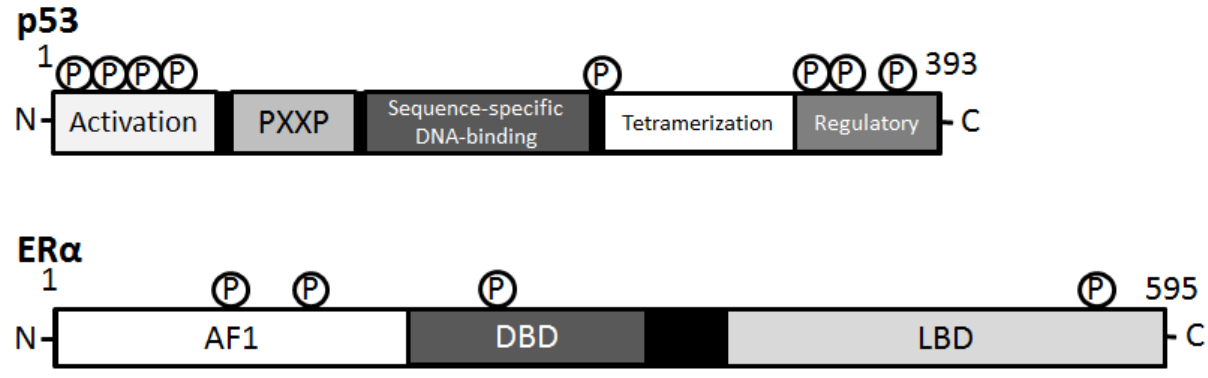

Figure 2: Schematic diagram representing the domain structures of ATM, p53, BRCA1, and ER (ER $\alpha$ ) proteins. The functionally important sites are depicted. The functionally key sites including the sites of protein phosphorylation are shown. Note that the sizes of protein are modified for clarity. HEAT = huntington, elongation factor 3, a subunit of PP2A and TOR1; FAT = FRAP-ATM-TRRAP; FATC = FAT-C-terminal; PXXP = a proline repeat; Ring = (Really Interesting New Gene) finger domain; NLS=Nuclear Localization Signal; BRCT=BRCA1 C Terminus; AF1=activation function 1; DBD=DNAbinding domain; LBD=ligand-binding domain

effects of certain hormonal therapy including prostate cancer [58].

Estrogen signaling stimulates the expression of genes such as BRCA1involved in DNA repair mechanism. However, chronic exposure to estrogen contributes to the induction of cancer in ER-positive cells (Figure 3). In general, cancer is a complicated disease which can get more aggressive, invasive, and therapyresistant, triggered by several molecular changes. Hormonal therapies commonly regulate cancer cell proliferation, and have providing improvements in survival rate to the hormonerelated diseases. Many candidate genes have been recognized as prostate cancer biomarkers involved in hormone synthesis and secretion [59]. Since p53 plays a key role in the regulation of genes-transcription encoding proteins involved in DNA repair, the modification of p53 appear to be a pivotal determinant of cell fate. The p53 is mutated and/or deleted in almost half of human 


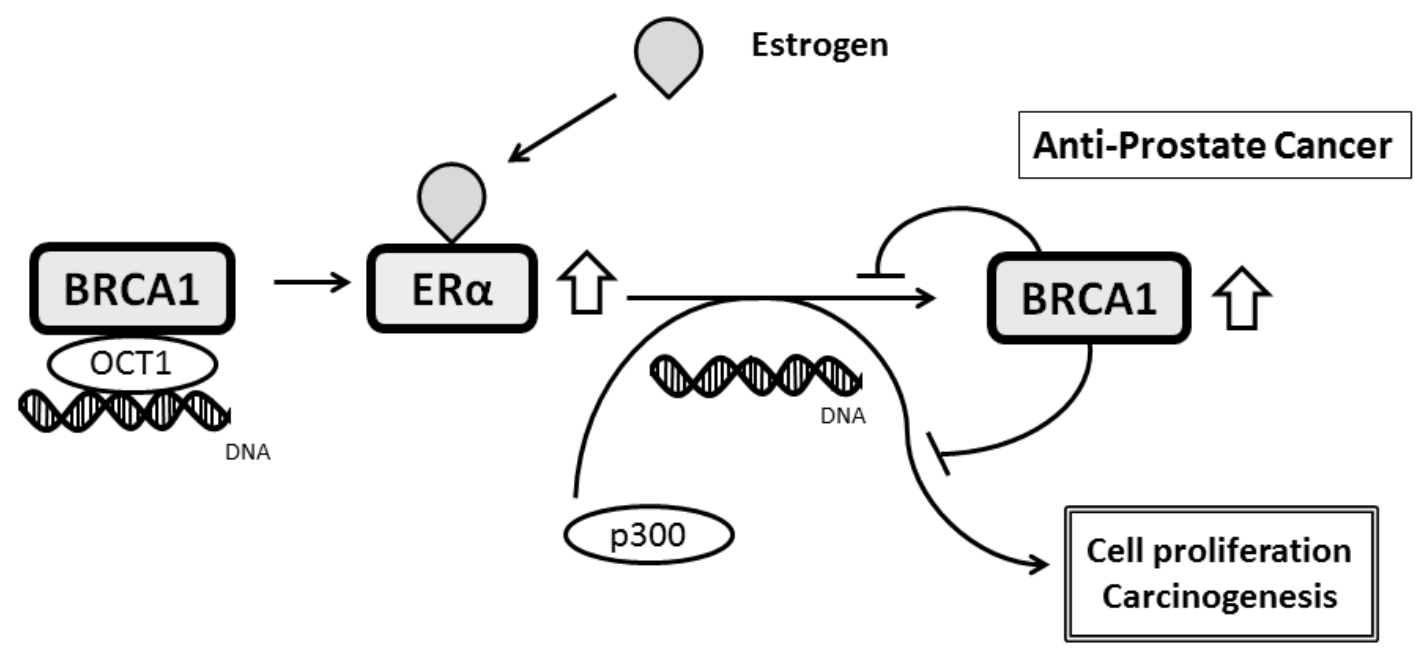

\section{Prostate Cancer}

Figure 3: Schematic depiction of the regulatory interplay between BRCA1 and ER $\alpha$. Estrogen stimulation increases the expression of BRCA1 through ER $\alpha$ transcriptional mechanism involving a transcriptional co-activator p300. BRCA1 regulates expression of ER $\alpha$ in an OCT1 dependent manner. On the other hand, BRCA1 protein can negatively regulate ER $\alpha$ mediated trans activation of the downstream genes. Note that some critical events have been omitted for clarity.

cancers during carcinogenesis [60,61], which fails to function normally. BRCA1 also plays a part in DNA recombination and repair processes related to maintenance of genomic integrity, and control of cell growth [62]. In general, normal cells show a good balance of the various mechanisms of the DNA repair. As mentioned above, estrogen metabolites can generate potentially mutagenic a purinic sites in the genomic DNA that is an obligatory cytotoxic intermediate in DNA base excision repair. BRCA1 stimulates the base excision repair pathway, a major mechanism for the repair of oxidized DNA, by stimulating the activity of key repair enzymes [63]. Most of BRCA1 mutant cancers are hormone receptor negative and some of hormonal factors may contribute to etiology of BRCA1 mutant cancers [64,65]. For example, the molecular mechanism of action of genistein in inducing cancer cell apoptosis is different either in BRCA1 blocked or in unblocked cells [66]. Prostate might be prone to accumulating genetic aberrations during epithelial regeneration due to a weaker ability to enforce DNA damage checkpoints [67].

\section{Relationship between DNA repair and prostate cancer via the estrogen signaling}

Suppression of DNA repair pathway seems to obstruct the mechanisms that are essential for cell survival, especially when in a presence of oncogenic mutations. Hence, DNA damaging agents work well in cancer cells with DNA repair defects for therapeutic sense [57]. Epigenetic mechanisms such as histone modifications and/or DNA methylation have also been evaluated with an understanding for improving cancer therapy via the regulation of genes-expression involved in DNA repair [68]. Several reports suggest that estrogen causes the epigenetic changes with histone modifications and DNA methylations in prostate as well as in other estrogen target organs. In addition, aberrant genomic DNA methylation can be observed in human prostate epithelial cells during environmental inorganic arsenic exposure [69]. Estrogeninduced malignancy in human prostate epithelial cells may be associated with genomic DNA hypo-methylation [70]. Actually, aberrant hypo-methylation of DNA is apparent in a variety of human diseases including cancer and diabetes.

Eukaryotic cells generally respond to the DNA damage by stopping the cell cycle to initiate DNA repair. Cancer cells due to the disruption in the p53-dependent pathway are mainly dependent on G2/M and S-phase checkpoints to keep the genomic integrity in response to the DNA damage. ER $\beta$ may inhibit prostate cell proliferation by regulating components of the cell cycle machinery in those cellular systems. It has been reported that induction of ER $\beta$ expression causes abolition of S-phase and Chk1-mediated checkpoints after cisplatin and doxorubicin exposure in p53-defective prostate cancer cells, but not in wildtype-p53cells. Therefore, in cancers where p53 is defective, the presence of ER $\beta$ may contribute to an effective response to cisplatin and doxorubicin chemotherapy [71].

Through the stress-induced activation, p53 appears to play an important role in maintaining a stable genome via the role in DNA repair and cell apoptosis by expression of the target genes which protect the genetic integrity of cells. While-p53 gene is often mutated in multiple cancer tissues, the mutant p53 can be categorized as a loss-of-function or a gain-of-function protein depending on the mutation-types [72]. Wildtype-p53 is basically inactive under normal physiological conditions. Then, it is activated in response to various types of DNA stresses. Activation of the p53 may lead to regression of existing cancer lesions, and hence may be important in preventing cancer development [73]. Failure of the DNA repair-activities may lead to the p53-mediated 
induction of apoptotic cell death [74]. BRCA1 satisfies the criteria for a tumor suppressor gene whose function is required to inhibit several cancer developments. Mutation of BRCA1 is associated with higher genomic instability in cells, which accelerates further mutation-rates of the other critical genes. Studies have established the roles for BRCA1 in DNA repair processes, DNA damage signaling, and the checkpoints of cell cycle [75]. In consistent with this, cells deficient for BRCA1 show chromosomal aberrations and genomic instability [75]. The cDNA of BRCA1 encodes for 1863 amino acids protein with two putative nuclear localization signals and an N-terminal zinc ring-finger motif (Figure 2).

The N-terminal domain possesses E3 ubiquitin ligase activity [76], whereas the C-terminal domain is involved in association with specific phospho-proteins [77]. On the other hand, BRCA1 gets hyper-phosphorylated after cell treatment with DNA damaging agents, and the function of BRCA1 seems to be specifically regulated by the phosphorylation-status [78]. In addition to the function in regulation of DNA damage responses, BRCA1 protein interacts with ER and androgen receptor, then, regulates their activities [79]. BRCA1 can act for inhibiting $\mathrm{ER} \alpha$ and for activating androgen receptor, respectively [80]. Therefore, BRCA1 mutations confer a considerable risk for each of hormone responsive cancers (Figure 3). Additionally, hormonal factors also contribute to the risk of carcinogenesis in BRCA1 mutation carriers. In other words, hormonal factors affect therapeutic chance of tumor cell killing via the modulation in DNA repair-levels of mechanism. Consequently, the DNA repairactivity in cells might be a novel therapeutic modality in certain cancers. Either survival or apoptosis determined by the balance between DNA repair levels and DNA damages, which may offer the major problems in cancer therapy [81]. Most men with prostate cancer who require treatment will be good candidates for a radio-therapeutic approach with DNA damages [82] Although the role of BRCA1 in prostate carcinogenesis remains unrevealed, harmful mutations in genes have been associated with more aggressive and poor clinical outcomes. In fact, one of the strong risk factors for prostate cancer is a family history of the disease [83]. BRCA1 may coordinate cell fate in response to genotoxic damages, suggesting that BRCA1 should be considered for the target of chemotherapeutic strategies in prostate cancer [84]. In addition, some changes in DNA repair molecules happen to sensitize prostate cancer cells to the effects of ionizing radiation [85].

\section{Perspective}

Since the hormone signaling pathways may play an essential role in the development of prostate cancer, hormonal therapy (such as androgen-deprivation) is the standard systemic treatment for advanced prostate cancer. However, it is obscure whether estrogens have beneficial effects on prostate cancer therapy, or not. Advances of molecular biology in a field of DNA repair have led to a better understanding of the events important in the molecular pathogenesis of hormonal cancers including prostate cancer. Different molecular bio-mechanisms of the action could be also favorable, suggesting a real application in prevention of prostate cancer. Estrogen signaling pathway has a complex network, and further comprehensive research in this area is obligatory. Discrepancy between the cell proliferation and DNA repair actions may be plausible for the accumulation of DNA errors, susceptible to prostate carcinogenesis, and the exacerbation of the cancer development. Precise understanding of the underlying molecular mechanisms involved in the transition to hormone refractory disease is also necessary for the improvement of effective therapeutic strategies. Mechanistic studies are mandatory in order to recognize these molecular mechanisms of hormonal carcinogenesis, cancer development, and the DNA repair system for the effective therapeutic interventions.

\section{Acknowledgments}

This work was supported by JSPS KAKENHI Grant Number 25560050, 26-12035, 24240098.

\section{References}

1. Cancel-Tassin G, Cussenot O. Prostate cancer genetics. Minerva Urol Nefrol. 2005. 57: 289-300.

2. Shaik AP, Jamil K, Das P. CYP1A1 polymorphisms and risk of prostate cancer: a meta-analysis. Urol J. 2009; 6(2):78-86.

3. Folkerd EJ, Dowsett M. Influence of sex hormones on cancer progression. J Clin Oncol. 2010; 28: 4038-4044. doi: 10.1200/ JC0.2009.27.4290.

4. Olea N, Pulgar R, Perez P, F Olea-Serrano, A Rivas, A Novillo-Fertrell, et al. Estrogenicity of resin-based composites and sealants used in dentistry. Environ Health Perspect. 1996; 104(3): 298-305.

5. Santti R, Newbold RR, Makela S, Pylkkanen L, McLachlan JA. Developmental estrogenization and prostatic neoplasia. Prostate. 1994; 24(2): 67-78.

6. Crawford ED. Complementary medicine, chemoprevention, and staging of prostate cancer. Rev Urol. 2003; 5(Suppl 6): S23-S32.

7. Crawford ED. The role of the urologist in treating patients with hormone-refractory prostate cancer. Rev Urol. 2003; 5(Suppl 2): S48-S52.

8. Ho CK, Habib FK. Estrogen and androgen signaling in the pathogenesis of BPH. Nat Rev Urol. 2011; 8(1): 29-41. doi: 10.1038/nrurol.2010.207.

9. Ricke WA, McPherson SJ, Bianco JJ, Cunha GR, Wang Y, Risbridger GP. Prostatic hormonal carcinogenesis is mediated by in situ estrogen production and estrogen receptor alpha signaling. FASEB J. 2008; 22(5):1512-1520.

10. Ricke WA, Wang Y, Cunha GR. Steroid hormones and carcinogenesis of the prostate: the role of estrogens. Differentiation. 2007; 75(9): 871882 .

11. Dahabreh IJ, Chung M, Balk EM, Yu WW, Mathew P, Lau J, et al. Active surveillance in men with localized prostate cancer: a systematic review. Ann Intern Med. 2012; 156(8): 582-590. doi: 10.7326/00034819-156-8-201204170-00397.

12. Liss MA, Schlicht M, Kahler A, Fitzgerald R, Thomassi T, Degueme A, et al. Characterization of soy-based changes in Wnt-frizzled signaling in prostate cancer. Cancer Genomics Proteomics. 2010; 7(5): 245-252.

13. Trottier G, Bostrom PJ, Lawrentschuk N, Fleshner NE. Nutraceuticals and prostate cancer prevention: a current review. Nat Rev Urol. 2010; 7(1): 21-30. doi: 10.1038/nrurol.2009.234. 
14. Niclis C, DíazMdel P, Eynard AR, Román MD, La Vecchia C. Dietary habits and prostate cancer prevention: a review of observational studies by focusing on South America. Nutr Cancer. 2012; 64(1): 2333. doi: 10.1080/01635581.2012.630163.

15. Wigle DT, Turner MC, Gomes J, Parent ME. Role of hormonal and other factors in human prostate cancer. J Toxicol Environ Health B Crit Rev. 2008; 11(3-4): 242-259. doi: 10.1080/10937400701873548.

16. de Rosa V, Erkekoğlu P, Forestier A, Favier A, Hincal F, Diamond AM, et al. Low doses of selenium specifically stimulate the repair of oxidative DNA damage in LNCaP prostate cancer cells. Free Radic Res. 2012; 46(2): 105-116. doi: 10.3109/10715762.2011.647009.

17. Bourke L, Sohanpal R, Nanton V, Crank H, Rosario DJ, Saxton JM. A qualitative study evaluating experiences of a lifestyle intervention in men with prostate cancer undergoing androgen suppression therapy. Trials. 2012; 13: 208. doi:10.1186/1745-6215-13-208

18. Qin LQ, Wang PY, Kaneko T, Hoshi K, Sato A. Estrogen: one of the risk factors in milk for prostate cancer. Med Hypotheses. 2004; 62(1): 133142 .

19. Yu S, Zhang Y, Yuen MT, Zou C, Danielpour D, Chan FL. 17-Beta-estradiol induces neoplastic transformation in prostatic epithelial cells. Cancer Lett. 2011; 304(1): 8-20. doi: 10.1016/j.canlet.2011.01.003.

20. Timms BG, Howdeshell KL, Barton L, Bradley S, Richter CA, vomSaal FS. Estrogenic chemicals in plastic and oral contraceptives disrupt development of the fetal mouse prostate and urethra. Proc Natl Acad Sci U S A. 2005; 102(19): 7014-7019.

21. Prins GS, Birch L, Tang WY, Ho SM. Developmental estrogen exposures predispose to prostate carcinogenesis with aging. Reprod Toxicol. 2007; 23(3): 374-382. doi: 10.1016/j.reprotox.2006.10.001.

22. Purohit A, Foster PA. Steroid sulfatase inhibitors for estrogen- and androgen-dependent cancers. J Endocrinol. 2012; 212: 99-110. doi: 10.1530/JOE-11-0266.

23. Banerjee S, Li Y, Wang Z, Sarkar FH. Multi-targeted therapy of cancer by genistein. Cancer Lett. 2008; 69: 226-242. doi: 10.1016/j. canlet.2008.03.052.

24.Zhao R, Xiang N, Domann FE, Zhong W. Effects of selenite and genistein on G2/M cell cycle arrest and apoptosis in human prostate cancer cells. Nutr Cancer. 2009; 61(3): 397-407. doi: 10.1080/01635580802582751.

25. Park S, Choi J. Inhibition of beta-catenin/Tcf signaling by flavonoids. J Cell Biochem. 2010; 110: 1376-1385. doi: 10.1002/jcb.22654.

26. Power KA, Thompson LU. Can the combination of flaxseed and its lignans with soy and its isoflavones reduce the growth stimulatory effect of soy and its isoflavones on established breast cancer? Mol Nutr Food Res. 2007; 51: 845-856.

27. Sánchez Y, Amrán D, Fernández C, de Blas E, Aller P. Genistein selectively potentiates arsenic trioxide-induced apoptosis in human leukemia cells via reactive oxygen species generation and activation of reactive oxygen species-inducible protein kinases (p38-MAPK, AMPK). Int J Cancer. 2008; 123: 1205-1214. doi: 10.1002/ijc.23639.

28. Langeberg WJ, Kwon EM, Koopmeiners JS, Ostrander EA, Stanford JL. Population-based study of the association of variants in mismatch repair genes with prostate cancer risk and outcomes. Cancer Epidemiol Biomarkers Prev. 2010; 19: 258-264. doi: 10.1158/10559965.EPI-09-0800.

29. Lacroix-Triki M, Lambros MB, Geyer FC, Suarez PH, Reis-Filho JS, Weigelt B. Absence of microsatellite instability in mucinous carcinomas of the breast. Int J Clin Exp Pathol. 2010; 27: 22-31.
30. Chen Y, Wang J, Fraig MM, Henderson K, Bissada NK, Watson DK, et al. Alterations in PMS2, MSH2 and MLH1 expression in human prostate cancer. Int J Oncol. 2003; 22: 1033-1043.

31. Norris AM, Woodruff RD, D'Agostino RB Jr, Clodfelter JE, Scarpinato KD. Elevated levels of the mismatch repair protein PMS2 are associated with prostate cancer. Prostate. 2007; 67: 214-225.

32. Bansal A, Soni A, Rao P, Singh LC, Mishra AK, Mohanty NK, et al. Implication of DNA repair genes in prostate tumourigenesis in Indian males. Indian J Med Res. 2012; 136(4): 622-632.

33. Soni A, Bansal A, Mishra AK, Batra J, Singh LC, Chakraborty A, et al. Association of androgen receptor, prostate-specific antigen, and CYP19 gene polymorphisms with prostate carcinoma and benign prostatic hyperplasia in a north Indian population. Genet Test Mol Biomarkers. 2012; 16(8):835-840. doi: 10.1089/gtmb.2011.0322.

34. Menasce LP, White GR, Harrison CJ, Boyle JM. Localization of the estrogen receptor locus (ESR) to chromosome 6q25.1 by FISH and a simple post-FISH banding technique. Genomics. 1993; 17(1): 263265.

35. Enmark E, Pelto-Huikko M, Grandien K, Lagercrantz S, Lagercrantz J, Fried G, et al. Human estrogen receptor beta-gene structure, chromosomal localization, and expression pattern. J ClinEndocrinolMetab. 1997; 82(12): 4258-4265.

36. Kuiper GG, Enmark E, Pelto-Huikko M, Nilsson S, Gustafsson JA. Cloning of a novel receptor expressed in rat prostate and ovary. Proc Natl Acad Sci U S A. 1996; 93(12): 5925-5930.

37. Klinge CM. Estrogen receptor interaction with estrogen response elements. Nucleic Acids Res. 2001; 29(14): 2905-2919.

38. Hyder SM, Chiappetta C, Stancel GM. Synthetic estrogen 17alphaethinyl estradiol induces pattern of uterine gene expression similar to endogenous estrogen 17beta-estradiol. J Pharmacol Exp Ther. 1999; 290(2): 740-747.

39. Hyder SM, Chiappetta C, Stancel GM. Interaction of human estrogen receptors alpha and beta with the same naturally occurring estrogen response elements. Biochem Pharmacol. 1999; 57(6): 597-601.

40. Wada-Hiraike O, Yano T, Nei T, Matsumoto Y, Nagasaka K, Takizawa S, et al. The DNA mismatch repair gene hMSH2 is a potent coactivator of oestrogen receptor alpha. Br J Cancer. 2005; 92: 2286-2291.

41. McPherson SJ, Hussain S, Balanathan P, Hedwards SL, Niranjan B, Grant M, et al. Estrogen receptor-beta activated apoptosis in benign hyperplasia and cancer of the prostate is androgen independent and TNF alpha mediated. Proc Natl Acad Sci U S A. 2010; 107(7): 3123 3128. doi: $10.1073 /$ pnas.0905524107.

42. Warner M, Gustafsson JA. The role of estrogen receptor beta (ERbeta) in malignant diseases--a new potential target for antiproliferative drugs in prevention and treatment of cancer. Biochem Biophys Res Commun. 2012; 396: 63-66. doi: 10.1016/j.bbrc.2010.02.144.

43. Liu MM, Albanese C, Anderson CM, Hilty K, Webb P, Uht RM, et al. Opposing action of estrogen receptors alpha and beta on cyclin D1 gene expression. J Biol Chem. 2002; 277(27): 24353-24360.

44. Schatzl G, Madersbacher S, Thurridl T, Waldmüller J, Kramer G, Haitel A, et al. High-grade prostate cancer is associated with low serum testosterone levels. Prostate. 2001; 47(1): 52-58.

45. Simon J, Klaiber E, Wiita B, Bowen A, Yang HM. Differential effects of estrogen-androgen and estrogen-only therapy on vasomotor symptoms, gonadotropin secretion, and endogenous androgen bioavailability in postmenopausal women. Menopause. 1999; 6(2): 138-146. 
46. Singh PB, Matanhelia SS, Martin FL. A potential paradox in prostate adenocarcinoma progression: oestrogen as the initiating driver. Eur J Cancer. 2008; 44(7): 928-936. doi: 10.1016/j.ejca.2008.02.051.

47. Perabo FG, Von Löw EC, Ellinger J, von Rücker A, Müller SC, Bastian PJ. Soy isoflavone genistein in prevention and treatment of prostate cancer. Prostate Cancer Prostatic Dis. 2008; 11(1): 6-12.

48. Ahmadi H, Allameh F, Baradaran N, Montaser-Kouhsari L, BazarganHejazi S, Salem S, et al. Circulating sex hormones play no role in the association between sexual activity and the risk of prostate cancer. J Sex Med. 2011; 8(3): 905-913. doi: 10.1111/j.1743-6109.2010.02115.x.

49. Mueck AO, Sitruk-Ware R. Nomegestrol acetate, a novel progestogen for oral contraception. Steroids. 2011; 76: 531-539. doi: 10.1016/j. steroids.2011.02.002.

50. Bolton JL, Thatcher GR. Potential mechanisms of estrogenquinone carcinogenesis. Chem Res Toxicol. 2008; 21: 93-101.

51. Cavalieri EL, Rogan EG. Unbalanced metabolism of endogenous estrogens in the etiology and prevention of human cancer. J Steroid Biochem Mol Biol. 2011;125: 169-180. doi: 10.1016/j. jsbmb.2011.03.008.

52. Yang L, Gaikwad NW, Meza J, Cavalieri EL, Muti P, Trock B, et al. Novel biomarkers for risk of prostate cancer: results from a case-control study. Prostate. 2009; 69: 41-48. doi: 10.1002/pros.20850.

53. Martin L, Coffey M, Lawler M, Hollywood D, Marignol L. DNA mismatch repair and the transition to hormone independence in breast and prostate cancer. Cancer Lett. 2010; 291: 142-149. doi: 10.1016/j. canlet.2009.10.007.

54. Kelly GL, Strasser A. The essential role of evasion from cell death in cancer. Adv Cancer Res. 2011; 111: 39-96. doi: 10.1016/B978-0-12385524-4.00002-7.

55. Bhatti S, Kozlov S, Farooqi AA, Naqi A, Lavin M, Khanna KK. ATM protein kinase: the linchpin of cellular defenses to stress. Cell Mol Life Sci. 2011; 68: 2977-3006. doi: 10.1007/s00018-011-0683-9.

56. Chiu YT, Liu J, Tang K, Wong YC, Khanna KK, Ling MT. Inactivation of ATM/ATR DNA damage checkpoint promotes androgen induced chromosomal instability in prostate epithelial cells. PLoS One. 2012; 7(12): e51108. doi: 10.1371/journal.pone.0051108.

57. Okumura N, Yoshida H, Kitagishi Y, Nishimura Y, Iseki S, Matsuda S. Against Lung Cancer Cells: To Be, or Not to Be, That Is the Problem. Lung Cancer Int. 2012; Article ID 659365, 8 pages, doi:10.1155/2012/659365.

58. Lee HJ, Chattopadhyay S, Yoon WH, Bahk JY, Kim TH, Kang HS, et al. Overexpression of hepatocyte nuclear factor-3alpha induces apoptosis through the upregulation and accumulation of cytoplasmic p53 in prostate cancer cells. Prostate. 2010; 70: 353-361. doi: 10.1002/ pros.21069.

59. Dumitrescu RG. Epigenetic markers of early tumor development Methods Mol Biol. 2012; 863: 3-14. doi: 10.1007/978-1-61779-6128_1.

60. Muller PA, Vousden KH, Norman JC. p53 and its mutants in tumor cell migration and invasion. J Cell Biol. 2011; 192: 209-218. doi: 10.1083/ jcb.201009059.

61. Essmann F, Schulze-Osthoff K. Translational approaches targeting the p53 pathway for anti-cancer therapy. Br J Pharmacol. 2012; 165: 328344. doi: 10.1111/j.1476-5381.2011.01570.x.

62. Karve TM, Li X, Saha T. BRCA1-mediated signaling pathways in ovarian carcinogenesis. Funct Integr Genomics. 2012; 12: 63-79. doi: 10.1007/s10142-011-0251-2.

63. Saha T, Rih JK, Roy R, Ballal R, Rosen EM. Transcriptional regulation of the base excision repair pathway by BRCA1. J Biol Chem. 2010; 285: 19092-190105. doi: 10.1074/jbc.M110.104430.

64. Berstein LM. Endocrinology of the wild and mutantBRCA1 gene and types of hormonal carcinogenesis. Future Oncol. 2008; 4: 23-39. doi: 10.2217/14796694.4.1.23.

65. Okumura N, Yoshida H, Kitagishi Y, Nishimura Y, Matsuda S. Alternative splicings on p53, BRCA1 and PTEN genes involved in breast cancer. Biochem Biophys Res Commun. 2011; 413: 395-399. doi: 10.1016/j. bbrc.2011.08.098.

66. Thasni KA, Rojini G, Rakesh SN, Ratheeshkumar T, Babu MS, Srinivas G, et al. Genistein induces apoptosis in ovarian cancer cells via different molecular pathways depending on Breast Cancer Susceptibility gene1 (BRCA1) status. Eur J Pharmacol. 2008; 588(2-3): 158-164. doi: 10.1016/j.ejphar.2008.04.041.

67. Jäämaa S, Laiho M. Maintenance of genomic integrity after DNA double strand breaks in the human prostate and seminal vesicle epithelium: the best and the worst. Mol Oncol. 2012; 6(5): 473-483. doi: 10.1016/j. molonc.2012.06.001.

68. Gigek CO, Chen ES, Calcagno DQ, Wisnieski F, Burbano RR, Smith MA. Epigenetic mechanisms in gastric cancer. Epigenomics. 2012; 4: 279294. doi: $10.2217 /$ epi.12.22.

69. Benbrahim-Tallaa L, Waalkes MP. Inorganic arsenic and human prostate cancer. Environ Health Perspect. 2008; 116(2): 158-164. doi: 10.1289/ehp.10423.

70. Benbrahim-Tallaa L, Waterland RA, Styblo M, Achanzar WE, Webber MM, Waalkes MP. Molecular events associated with arsenic-induced malignant transformation of human prostatic epithelial cells: aberrant genomic DNA methylation and K-ras oncogene activation. Toxicol Appl Pharmacol. 205; 206(3): 288-298.

71. Thomas CG, Strom A, Lindberg K, Gustafsson JA. Estrogen receptor beta decreases survival of p53-defective cancer cells after DNA damage by impairing $\mathrm{G}_{2} / \mathrm{M}$ checkpoint signaling. Breast Cancer Res Treat. 2011; 127(2): 417-427. doi: 10.1007/s10549-010-1011-z.

72. Martinez-Rivera M, Siddik ZH. Resistance and gain-of-resistance phenotypes in cancers harboring wild-type p53. Biochem Pharmacol. 2012; 83: 1049-1062. doi: 10.1016/j.bcp.2011.12.026.

73. Stegh AH. Targeting the p53 signaling pathway in cancer therapy - the promises, challenges and perils. Expert Opin Ther Targets. 2012; 16: 67-83. doi: 10.1517/14728222.2011.643299.

74. Zawacka-Pankau J, Krachulec J, Grulkowski I, Bielawski KP, Selivanova G. The p53-mediated cytotoxicity of photodynamic therapy of cancer: recent advances. Toxicol Appl Pharmacol. 2008; 232(3): 487-497. doi: 10.1016/j.taap.2008.07.012.

75. Roy R, Chun J, Powell SN. BRCA1 and BRCA2: different roles in a common pathway of genome protection. Nat Rev Cancer. 2011;12: 6878. doi: $10.1038 / \operatorname{nrc} 3181$.

76. Ohta T, Sato K, Wu W. The BRCA1ubiquitinligase and homologous recombination repair. FEBS Lett. 2011; 585: 2836-2844. doi: 10.1016/j.febslet.2011.05.005.

77. Leung CC, Glover JN. BRCT domains: easy as one, two, three. Cell Cycle. 2011; 10: 2461-2470.

78. Ouchi T. BRCA1phosphorylation: biological consequences. Cancer Biol Ther. 2006; 5: 470-475. 
79. Kotsopoulos J, Narod SA (2012) Androgens and breast cancer. Steroids 77: 1-9.

80. Rosen EM, Fan S, Isaacs C. BRCA1 in hormonal carcinogenesis: basic and clinical research. Endocr Relat Cancer. 2005; 12(3): 533-548.

81. Okumura N, Yoshida H, Kitagishi Y, Nishimura Y, Iseki S, Matsuda S. Against Lung Cancer Cells: To Be, or Not to Be, That Is the Problem. Lung Cancer Int. 2012. Doi: 10.1155/2012/659365.

82. Soloway MS, Soloway CT, Eldefrawy A, Acosta K, Kava B, Manoharan M. Careful selection and close monitoring of low-risk prostate cancer patients on active surveillance minimizes the need for treatment. Eur Urol. 2010; 58(6): 831-835. doi: 10.1016/j.eururo.2010.08.027.
83. Castro E, Eeles R. The role of BRCA1 and BRCA2 in prostate cancer. Asian J Androl. 2012; 14(3): 409-414. doi: 10.1038/aja.2011.150.

84. De Luca P, Vazquez ES, Moiola CP, Zalazar F, Cotignola J, Gueron G, et al. BRCA1 loss induces GADD153-mediated doxorubicin resistance in prostate cancer. Mol Cancer Res. 2011; 9(8): 1078-1090. doi: 10.1158/1541-7786.MCR-11-0155.

85. Bais MV, Ozdener GB, Sonenshein GE, Trackman PC. Effects of tumorsuppressor lysyl oxidase propeptide on prostate cancerxenograft growth and its direct interactions with DNA repair pathways. Oncogene. 2014; 2;0. doi: 10.1038/onc.2014.147. 